\title{
The Financial Crisis of 2008 and Its Impact on the Asian Rice Export Market
}

\author{
Frank Canovatchel ${ }^{1}$ \\ ${ }^{1}$ IT\&S Division, CIT Program, Champlain College, Burlington, United States \\ Email: frank.canovatchel@gmail.com
}

\begin{abstract}
There are many studies that have analyzed the market for rice exports in terms of two or three major Asian rice-exporting countries. To date, there is no work that analyzes the behavior of the four major Asian rice exporters. Using export prices from the world's leading Asian rice exporting countries: Thailand, Vietnam, Pakistan and India, this article examines market behavior and how the financial crisis of 2008 impacted the evolution of this market's pricing behavior. Given that more than half of the world's population depends on rice as part of its caloric intake and food security, efficient price formation is critical to maintaining price stability. The impact of U.S. rice export prices is not considered in this work because the United States is an entity outside of this market economically and geographically speaking. The financial crisis of 2008 had a major impact on grain prices and, more specifically, on rice supplies and prices. This work will examine the market pre-crisis and post-crisis to demonstrate that this market is evolving from coherent and defined export market to a more independent and less price oriented export market. This work examines real export prices of $5 \%$ broken rice from July 2002 to December 2015 from these four countries. The model employed uses FGLS regression using panel data.
\end{abstract}

Keywords: Financial crisis, rice exports, Asian rice export market

\section{Introduction}

Rice is a critical dietary component of more than half the world's population. Securing this commodity and providing price stability increases the food security of the main importing nations of the world. This article examines the formation and behavior of the rice market from the producer's perspective.

In the literature, there are many studies that examine the rice market in terms of two or three of these exporting countries. To date, there are no studies that examine this market uniquely in terms of India, Pakistan, Thailand and Vietnam, acting as one coherent export market. This study examines price determination and how these exporters view the market from a producer's perspective.

The first part of this paper presents a background on rice consumption patterns and the major importers and exporters. The second part is a literature review on the rice market and price formation. Part three identifies the nations that constitute the Asian rice export market and how the literature defines the market structure of two to three of these countries. Part four introduces the methodology employed, and the data used in this work. Part five provides the model and tests used to determine how this market works to determine export pricing and the last part provides conclusions and recommendations for further study.

\section{$2 \quad$ Background}

Rice is a staple in the diet and culture of over 3 billion people throughout the world. According to Reddy (2006), Chen, McCarl, Chang (2006), Timmer (2009), it is the second largest grain produced, and about half the world's population depends on it as a staple in their diet. For most developing nations, access to rice is essential to their overall food security plan.

1 "Global Climate Changes and Rice Food Security", N.V. Nguyen, Executive Secretary, International Rice Commission, FAO, Rome, Italy, 2008, Pg. 3. 
During the financial crisis of 2008, the price of rice and other grains spiked to record levels. This posed an immediate threat to the food security of African and Asian countries that depend on rice as a main food staple ${ }^{2}$.

The pattern of increasing rice export prices starting in 2002, to the advent of the 2008 financial crisis, is seen in both low and high quality rice export prices. Both categories spiked to record levels during the crisis and then exhibited volatility in the post-crisis period. For low-income countries, this represents a direct threat to their food security.

From October 2007 to January 2008, the price of high quality rice exports rose between 3 to 4 percent each month. For low-quality rice exports during the same time period the increase was between 3 to 5 percent per month. In the first quarter of 2008, the monthly increase in export prices of low-quality rice was between 20.4\% (January 2008) and 35.6\% (March 2008). For high quality rice exports, the range of price increases was between 24.3\% (February 2008) and 36.4\% (March 2008) . $^{3}$

As shown in Table 1 below, rice is important as an export commodity to the Asian market. Rice contributes to the overall export value and volume of these countries. Awareness of the price determinants for rice exports will allow these countries to know what the market will bear with regard to their export pricing.

Table 1: Volume of Asian rice exports (September 2016)

\begin{tabular}{l|l|l}
\hline Country & Volume (in MT) & Share of Asian Rice Exports to the World \\
\hline India & 950 & $23 \%$ \\
\hline Thailand & 900 & $22 \%$ \\
\hline Vietnam & 640 & $16 \%$ \\
\hline Pakistan & 425 & $10 \%$ \\
\hline
\end{tabular}

Source: USDA-FAS, October, 2016

Thailand and India account for over $45 \%$ of the volume of rice exports with Pakistan and Vietnam making up $26 \%$ of Asian rice exports. In global terms, these nations account for a significant percentage of the global rice trade.

Rice is mainly cultivated by small farmers in paddies that are less than one hectare in size. Price stability is crucial for these farmers who are vulnerable to adverse price shocks ${ }^{4}$. Calpe (2006) and Imai (2011) note that laborers who work in urban areas are susceptible to, and are adversely affected by, price shocks.

Most of the rice from this market is exported to Asian and African countries. According to the Vietnam Trade Promotion Agency, the largest importers of rice include the Philippines (34\%), Singapore (15\%) and Malaysia (10\%). Pakistan exports the largest amount of its rice to the UAE, Somalia, the Philippines, and Iran. India's major export markets include the UAE (22\%), Saudi Arabia $(22 \%)$, Iran (18\%), and Kuwait (9\%). Thailand's major export markets include Nigeria (14\%), Iraq (6\%), and Cote d'Ivoire (5\%).

\section{Identifying the Asian Rice Export Market}

There is evidence in the literature that it is a competitive market, as well as a non-competitive market. In a perfectly competitive market, no consumer or producer can influence price. Given this characteristic, this work will examine the ability of one or more producers to influence export price. What distinguishes this work from prior studies is that it considers all four major Asian rice exporting countries as one market.

Understanding the structure of the Asian rice export market is important for several reasons. First, if there is a transmission process of prices to or from the domestic market and the export market, the

\footnotetext{
${ }^{2}$ http://www.irri.org/index.php?option=com_k2\&view=item\&layout=item\&id=9081

${ }^{3}$ These calculations are by the author. The calculations are based on data from the FAO GIEWS data tool, InfoArrozo web site, All India Rice Exporters Association, and the World Bank GEM database.

${ }^{4}$ Calpe, Concepcion, "Rice International Commodity Profile", FAO, Markets and Trade Division, 2006.
} 
market structure will impact the rate of speed of this transmission (Reddy, 2006). For the purpose of definition, this work identifies an imperfect market whereby the producer can influence prices and/or the speed of price transmission between market sectors 5 . A market is considered competitive if producers in the market cannot influence prices in their favor. Even if governments are in control of entering into rice export contracts, they are still bound by market forces if these governments cannot influence price.

Markets must be free, open and efficient to support market price discovery. It is necessary for buyers and sellers through their interaction in the market to objectively discover the price of any given commodity. Mitchell and Duncan (1987) define the rice export market as an oligopoly, with the United States as the price leader in the market. Up until their publication, most of the research on this topic focused on determining market structure rather than market behavior. Their work developed a model of export participant's behavior in the market to prove that the market structure was an oligopoly.

In Mitchell and Duncan, their focus is on behavior, since, in an oligopoly, if few producers are competing with each other and cannot influence price, then an oligopoly does not exist since no firm is a price leader. When the market has a dominant price leader, the leader sets prices and the non-dominant exporters are price takers. The range of behaviors is from collusion of producers to competition. They define this market as having a dominant exporter and price leader, identified as the United States. The smaller exporters are identified as China, Pakistan, Japan, and Thailand. The dominant exporter sets the market price and will maximize profits where $\mathrm{MC}=\mathrm{MR}$.

All of the smaller exporters will behave as perfectly competitive suppliers in the market with the price set by the market leader and will face elastic demand from importing nations. Each of the suppliers will also maximize their profits where $\mathrm{MC}=\mathrm{MR}$.

Yumkella et al (1994) conclude that the rice export market, as they defined it, is segmented into competitive and non-competitive market structures. They recognize that their study covers only a small part of the overall market and caution that no one should conclude that the entire market is noncompetitive.

Their study found that market structure in some importing countries would support non-competitive pricing, but they did not provide any details as to what market structures exist that would make this possible. When they found strong evidence of non-competitive pricing it was attributed to imperfect exchange rate pass-through.

Chulaphan, Chen, Jatuporn and Huang (2013) analyze the rice export market to determine if these markets are integrated or whether a long-run equilibrium relationship exists with prices of the major exporters. They divide the market into two distinct sectors. The first one is the export market for high quality rice which is defined as $5 \%$ broken rice, and the second is the market for low quality rice defined as $25 \%$ broken rice. They identify the leading exporters in each market as the United States, Thailand and Vietnam. The leading exporters of low quality rice include Pakistan, Vietnam and Thailand.

In Chulaphan, Chen and Huang the data used is monthly F.O.B. export price from January 1998 to April 2012. India is excluded from the study since it abandoned the export market from 2008 through 2010. They applied a statistical test to determine the existence of a unit root and for cointegration of the variables. They found that there is a long-run equilibrium relationship in the high-quality rice market between the U.S., Vietnam and Thailand. This long-run relationship exists in the low-quality rice export market between all participants.

They also found that the speed of adjustment to price shocks was fastest with Vietnam's export prices. Their study also concluded that Vietnam and Thailand each influenced the other export price for highquality rice. In the low-quality rice export market, they found that Pakistan's prices influenced Vietnam's prices, which in turn influenced Thailand's export prices.

Ghosray (2008) shows that Vietnam's pricing of rice exports was closely linked to Thailand's prices. For high-quality ( $5 \%$ broken rice) rice there is a long-run relationship and the adjustment process is asymmetric. The M-TAR model utilized by Ghosray shows that the adjustment is faster when the price differential is decreasing. He interprets the results as Vietnam is becoming more competitive in highquality rice exports. Also, Vietnam entered the high-quality rice export market when prices were declining therefore it had to lower its rice export prices at a faster rate to stay competitive with Thailand to maintain its market share. For low-quality rice ( $25 \%$ broken rice) the results show that the

\footnotetext{
${ }^{5}$ These sectors are the domestic market and wholesale market within a rice exporting nation as well as the
} international market and the commodities market. 
adjustment is symmetric. This indicates that both Vietnam and Thailand's rice export prices move together over time regardless of the direction of price movement.

Thi Duong Nga and Lantican (2009) examine the dynamic relationship of export prices between Vietnam and Thailand. They define $5 \%$ broken rice as high-quality rice and $25 \%$ broken rice as lowquality rice. Their results are similar to Ghoshray insofar as they find export prices of Vietnam and Thailand are cointegrated. They also test to see if the Law of One Price holds for this market which they conclude does, for both the $5 \%$ and the $25 \%$ broken rice export prices. This conclusion implies that the market for Thailand's and Vietnam's rice exports is competitive.

Clarete (2012) notes that the market for rice exports is competitive, as well as several key indicators that directly impact supply factors. These supply factors are deteriorating water, land use for rice, high crude oil prices, relationship between rice prices and other commodity prices. The reduced stock-to-use ratios for rice were the contributing demand-side factors contributing to export price volatility ${ }^{6}$.

An assumption about the rice export market is that it is free of government interference ${ }^{7}$. Therefore, market participants can freely enter or leave the market, and all information is free and available. Importers and exporters of rice can place tender offers either with governments or with trading houses that specialize in the rice trade. Neither the supplier nor the consumer controls the process. Any offer can be accepted or rejected. If all tender offers are rejected, then the importing or exporting agent can make a new bid or leave the market. The working mechanisms of the market are characteristics of a competitive market.

If the market is competitive then neither exporters nor importers can influence market price. This does not discount how a single exporter can influence market forces, which in turn exerts pressure on market prices. In 2008, the government of India banned non-basmati rice exports to protect domestic rice prices. As noted earlier in this work, the act of a supplier freely leaving the market resulted in the price of all rice types increasing. India's act of exiting the market had an effect on rice export prices. Timmer (2009) explains India's action as a supply shock to the market. He notes this action as an agent freely leaving the market, and not an agent exerting price influence for its own benefit.

The government of Vietnam responded to India's ban by suspending all rice contract negotiations that were underway. It also banned all trading houses in Vietnam from making tender offers or bidding on import tender offers from importing countries. Later, Vietnam lifted the ban and imposed its own minimum export price (MEP) policy. Pakistan imposed an MEP on its basmati rice exports. These actions in the market led to a spike in prices during the crisis of 2008. As Timmer (2009) noted when the WTO allowed Japan to re-export rice it imported from the United States to this market, prices began to decline. This demonstrates the ability of an agent to freely enter and then leave the market. It also demonstrates how market participants can freely respond to supply and demand shocks.

Many studies in the literature that discuss rice market formation use nominal monthly export price. This study uses real rice export prices deflated by each exporter's CPI. The empirical analysis will examine the competitiveness of this market ${ }^{8}$ and if the Law of One Price holds. The Law of One Price states that the price of a given commodity should have the same price in all countries when expressed in terms of a single currency.

High-quality rice exports are heterogeneous given that there are perceived quality differences between Basmati (India, Pakistan), Hom Mali (Thailand) and Vietnam's paddy rice. These rice exports range in $2 \%$ to $5 \%$ broken quality which is why they are considered high-quality rice. The heterogeneity of rice in general contributes to the overall rice market being a highly-segmented market ${ }^{9}$. Market segmentation should be a factor that results in each exporter acting independently and therefore creating its own export market. For the purpose of this work, basmati and other rice not classified as $5 \%$ broken rice, are excluded from analysis. Strictly using real export prices of $5 \%$ broken rice permits the analysis of a homogenous commodity.

\footnotetext{
6 "Enhancing ASEAN's Resiliency to Extreme Rice Price Volatility", Ramon L. Clarete, Asian Development Bank, ADB Sustainable Development Working Paper Series, No. 23, August 2012.

${ }^{7}$ Though the impact of government export policy on export prices is not specifically addressed in this study, it cannot be ignored as a potential factor in contributing to the spike in price prices.

${ }^{8}$ The market is competitive insofar as no one exporter can dominate the pricing of rice exports over the other market agents.

${ }^{9}$ Jamora and von Cramon-Taubadel, "What World Price?" Global Food Discussion Papers, No. 17, 2012, pg.9.
} 
There is not a consensus on the world price for rice. Thailand's dominance of the market has led to Thai $5 \%$ broken rice export prices to be considered the de facto world price. Given the abundance of data for milled Thai $5 \%$ broken rice, it has been used as a benchmark price for rice exports. With the market being highly segmented, the conclusion of Jamora and von Cramon-Taubadel (2010), is that there is no one world price for rice suggesting multiple markets for rice.

Kang, Kennedy and Hilbun (2009) discuss the monopoly power of Thailand, India, Vietnam and the United States. They note that structural changes in the market have contributed to increased rice trade volume and the decreasing speed at which rice exports decline relative to other grains. Yet even with these changes the market remains volatile and segmented. Jamora and von Cramon-Taubadel (2012) research confirms market segmentation. They attribute market segmentation to the various qualities of rice that are sold in the global market.

The focus of this work is on high-quality rice exports which represent a significant segment of the overall global market for rice. The data used in this work is the real monthly export prices of India, Pakistan, Thailand and Vietnam for $5 \%$ broken rice. The studies cited in this work, to this point, use cointegration tests as a means to determine if the Law of One Price holds. If the export prices of market participants are cointegrated, then the conclusion is that the Law of One Price holds, and the market is competitive. If prices in this market are cointegrated it provides important insight about the structure of the market. It also allows for an extended analysis of market formation.

The main sources of data used include the FAO, the World Bank, and various government databases of Vietnam, Thailand, India, and Pakistan.

\section{Data Analysis}

The data is comprised of monthly real rice export prices (F.O.B.) from India, Pakistan Thailand and Vietnam. Real export prices were calculated by deflating nominal export prices by each county's CPI. The data is analyzed as an unbalanced pool and the time period of the data is from August 2002 through December 2015. There are missing observations in the data for various reasons. India suspended exports from January 2009 through June 2011. In some instances, there is no price data for India or Pakistan.

The process begins by examining a panel VAR model as shown in Equation (1) below with a k-period lag which is determined by minimizing the AIC and SBIC for periods 1 through 12. The purpose for beginning with Equation 1 is to test for cross-section dependence using each exporter's price. First generation unit root tests assumed that cross sectional data was independent. There are econometric methods for measuring cross-section dependency as well as unit root tests that return valid results when cross-section dependence exists. Some of these include Breusch-Pagan (1979), Pesaran (2004) and Baltagi, Feng, and Kao (2012). The dependent variable $\Delta y_{i, t}$ is an $\mathrm{N}$ x 4 matrix of the natural log of export prices at time $t$ for the exporting countries used in this study. The value of $\Delta y_{i, t}$ is lagged for periods 1 through 12. The AIC and SBIC results for each lagged value are noted in Appendix $\mathrm{C}$ with the minimized AIC and SBIC chosen as the appropriate lag of the variable on the right-hand side in the VAR model.

$$
\Delta y_{i, t}=\alpha+\Delta y_{i, t-k}+e_{i, t}
$$

There are four panel cross-sectional dependency tests conducted on the data. Each result uses four cross-sections with a total unbalanced pool of 614 observations and 161 periods.

Ignoring cross-section dependence can lead to inefficient estimators and invalid test statistics. One test for cross-sectional dependence is the Breusch-Pagan test. Breusch and Pagan (1980) developed the LM approach to determine if cross section dependency exists. Pesaran (2004) and Baltagi, Feng, and Kao (2012) developed tests for cross-section dependency when $\mathrm{N}$ is large and $\mathrm{T}$ is small. Pesaran noted that for data where $\mathrm{T}$ is large and $\mathrm{N}$ is small, Breusch-Pagan test provides statistically significant results. Breusch-Pagan defined a SURE panel model as a system written as:

$$
y_{i t}=\beta X_{i t}+u_{i t}
$$

where OLS is used to derive the residuals used in the LM test. The null of the LM test is stated as $H_{0} \mathrm{r}_{i j}=0$ and $i \neq j$ where $r_{i j}$ is the correlation coefficient between the residuals $u_{i t} u_{j t}$ and defined as: 


$$
r_{i j}=N^{-1}\left(\tilde{\sigma}_{i i} \tilde{\sigma}_{j j}\right)^{-1 / 2} \tilde{u}_{i}^{\prime} \tilde{u}_{j}
$$

The Breusch-Pagan LM statistic is calculated as:

$$
L M=N \sum_{i=1}^{m} \sum_{j=1}^{i-1} r_{i j}^{2}
$$

The model in Equation 1 above minimized the AIC and the SBIC using the first lag of the operator. The results of the cross-sectional dependency tests are presented in Table 2 below.

Table 2: Residual cross-section dependence test

\begin{tabular}{l|l|l|l}
\hline Test & Statistic & d.f. & Prob. \\
\hline Breusch-Pagan LM & 273.3787 & 6 & 0.0000 \\
\hline
\end{tabular}

The null hypothesis for the test is that there is no cross-sectional dependency among the countries in this study. The results clearly support rejecting the null and concluding that there is cross-sectional dependency.

To test for a unit root in panel data that is cross-sectional dependent, the Im, Pesaran and Shin is employed. It assumes an individual intercept and can have a trend or no trend. This test allows for the cross-sections to be dependent while providing reliable results about the presence of a unit root.

The IPS framework assumes a stochastic process where $y_{i t}$ is determined by an AR(1) process as defined in Equation (5) below:

$$
y_{i t}=\left(1-\phi_{i}\right) \mu_{i}+\phi_{i} y_{i, t-1}+\varepsilon_{i t}
$$

for $i=1 \ldots, N t=1, \ldots T$. Eq. 5 is simplified to:

$$
\Delta y_{i t}=\alpha_{i}+\beta_{i} y_{i, t-1}+\varepsilon_{i t}
$$

where $\alpha_{i}=\left(1-\phi_{i}\right) \mu_{i}, \beta_{i}=-\left(1-\phi_{i}\right)$ and $\Delta y_{i t}=y_{i t}-\Delta y_{i, t-1}$. The null of the test is $H_{0}: \beta_{i}=0$ for all i with the alternative hypothesis stated as $H_{1}: \beta_{i}<0, i=1,2 \ldots, N_{1}, \beta_{i}=0, i=N_{1}+1, N_{1}+2, \ldots, N$.

The alternative hypothesis allows the value of $\beta_{i}$ to differ across groups such that some, but not all, cross-sections have a unit root present. The test is conducted using a trend and no trend. Table 3 below provides the results of this test.

Table 3: Im, Pesaran and Shin W-stat test results

\begin{tabular}{l|l|l}
\hline Effects & Statistic & Probability \\
\hline Individual intercept, no trend & -0.08796 & 0.4650 \\
\hline Individual intercept and trend & 0.87223 & 0.8085 \\
\hline
\end{tabular}

The null hypothesis of the test is that an individual unit root process in the export prices of India, Pakistan, Thailand and Vietnam does exist. The probabilities of a unit root are calculated assuming asymptotic normality. The total number of observations used is 599, with four cross-sections. An automatic lag length is determined by using the SBIC testing with lags of one to six periods. The test statistic is equal to -0.08796 and the t-statistic is equal to 0.4650 , which leads to the conclusion to not reject the null of an individual unit root process in the data. To remove the unit root process, the data is differenced. The unit root test using the first difference of data is conducted using 590 observations with four cross-sections. The probabilities are computed assuming asymptotic normality.

Testing the data for a unit root and using its first difference, the Im, Pesaran and Shin test results leads to concluding to rejecting the null of an individual unit root process. The results of this test are shown in Table 4 below.

Table 4: Im, Pesaran and Shin W-stat test results 1st diff.

\begin{tabular}{l|l|l}
\hline Effects & Statistic & Probability \\
\hline Individual intercept, no trend & -13.1986 & 0.0000 \\
\hline Individual intercept and trend & -13.0659 & 0.0000 \\
\hline
\end{tabular}




\section{$5 \quad$ Market Analysis}

The model tested begins with an $\mathrm{AR}(1)$ process of real high quality rice export prices illustrated in Eq. 5 below. Because there is cross-section dependence, OLS produces consistent but inefficient estimators. To correct for cross-section dependency where $\mathrm{T}>\mathrm{N}$, a Feasible Generalized Least Squares (FGLS) is used to estimate the model.

Homosckedasticity exists when $E[\epsilon \epsilon]=\sigma^{2} I$. If this assumption is relaxed then $E[\epsilon \epsilon]=\sigma^{2} \Omega$ where $\Omega$ is an $n x n$ invertible, symmetric matrix. Each element of the $\Omega$ matrix is proportional to the covariance between the error terms. The diagonal terms of the $\Omega$ matrix, $\omega_{i}$ are proportional to the variance of $\varepsilon_{i}$. Though the parameter estimates are consistent and not biased, the standard errors are incorrect, which leads to incorrect significance tests. In the case of heteroskedasticity OLS will not provide an estimate with the smallest variance.

An option to correct for heteroskedasticity is to use a General Least Squares (GLS) estimator. The variance of an estimated parameter is defined as:

$$
\begin{gathered}
\operatorname{Var}(\hat{\beta})=E[(\hat{\beta}-\beta)(\hat{\beta}-\beta) \\
\operatorname{Var}(\hat{\beta})=E\left[\left(X^{\prime} X\right)^{-1} X^{\prime} \epsilon \epsilon^{\prime} X\left(X^{\prime} X\right)^{-1}\right. \\
\operatorname{Var}(\hat{\beta})=E\left[\left(X^{\prime} X\right)^{-1} X^{\prime} \Omega X\left(X^{\prime} X\right)^{-1}\right.
\end{gathered}
$$

The $\Omega$ matrix is generally unknown since the process that determines $\epsilon$ is unknown. GLS uses a weighting process so that the observations with lower variance are weighted more heavily than those with higher variances. This process creates a result where the weights are applied to those observations that will better explain the variability of the dependent variable. To accomplish this an $n x n$ matrix, $\Psi$ is created as a weight for low variance observations. Using this process the variance of the error term is defined as:

$$
\begin{gathered}
\operatorname{Var}(C \epsilon)=E\left[C \epsilon \epsilon^{\prime} C^{\prime}\right]=\sigma^{2} I \\
C^{\prime} C=\Omega^{-1}
\end{gathered}
$$

Weighting all of the variables in the model by $C$ yields:

$$
\begin{gathered}
C y=C X \beta+C \epsilon \\
\hat{\beta}^{g l s}=\left[(C X)^{\prime}(X C)\right]^{-1}(C X)^{\prime} C y \\
\hat{\beta}^{g l s}=\left[\left(X^{\prime} C^{\prime} C X\right]^{-1} C^{\prime} X^{\prime} C y\right. \\
\hat{\boldsymbol{\beta}}^{g l s}=\left[X^{\prime} \Omega^{-1} X\right]^{-1} X^{\prime} \Omega^{-1} y
\end{gathered}
$$

The variance-covariance matrix is defined as:

$$
\operatorname{Var}\left(\hat{\beta}^{g l s}\right)=\sigma^{2}\left(X^{\prime} \Omega^{-1} X\right)
$$

In this work, the weighting process uses cross section weights to correct for heteroscedastic cross sections. The initial model tested is a 1-period lag of the dependent variable as shown in Equation (17) below. The reason for using no more than a 1-period lag is based on the results the AIC and the SBCI discussed earlier in this work.

$$
\Delta y_{t}=\alpha+\beta_{1} \Delta y_{t-1}+\epsilon_{t}
$$

The regression includes 160 price observations with four cross-sections. The panel cross sections are represented by the four exporting countries of India, Pakistan, Thailand and Vietnam. The results of this process are provided in Table 5 below: 
Table 5: Full period FGLS estimation

\begin{tabular}{l|l|l|l}
\hline Measurement $^{\mathrm{a}}$ & Value & Measurement & Value \\
\hline Coefficient & 0.4684 & Coefficient & 0.3424 \\
\hline t-Stat. & 13.06 & t-Stat. & 8.88 \\
\hline Prob. & $0.0000^{* * *}$ & Prob. & $0.0000^{* * *}$ \\
\hline $\mathrm{R}^{2}$ & 0.22 & $\mathrm{R}^{2}$ & 0.12 \\
\hline Adj. $\mathrm{R}^{2}$ & 0.22 & Adj. $\mathrm{R}^{2}$ & 0.12 \\
\hline DW Stat. & 1.96 & DW Stat. & 2.00 \\
\hline a - Uses cross-section weighting \\
\hline b - Uses cross-section SUR weighting \\
\hline
\end{tabular}

In all of the regressions presented in this section the intercept coefficient never significantly different than zero. The results indicate that the market's price changes are influenced by prior period prices. The coefficient is significant at the $1 \%$ level indicating that prior prices do impact current export prices. To understand how the financial crisis impacted market behavior, two regressions are performed. The first is a pre-crisis regression that encompasses the period defined as September 2002 through December 2008. The second period is the post-crisis period defined as June 2011 through December 2015.

A "price leader" is defined as an exporter whose change in export price influences other exports to do the same in the market. A "price follower" is an exporter who responds to a price leader's change in price. The follower will change its export price in the same direction but not necessarily by the same magnitude. If there is no price leader then it is a competitive market, whereby all agents move prices in accordance with their perceptions of what price the market will bear. Table 6 and Table 7 below provide the results of the pre-and post-crisis regressions.

Table 6: Pre-Crisis FGLS estimation

\begin{tabular}{l|l|l|l}
\hline Measurement $^{\mathrm{a}}$ & Value & Measurement $^{\mathrm{b}}$ & Value \\
\hline Coefficient & 0.5256 & Coefficient & 0.3642 \\
\hline Std. Error & 0.0489 & Std. Error & 0.0538 \\
\hline t-Stat. & 10.74 & t-Stat. & 6.77 \\
\hline Prob. & $0.0000^{* * *}$ & Prob. & $0.0000^{* * *}$ \\
\hline $\mathrm{R}^{2}$ & 0.28 & $\mathrm{R}^{2}$ & 0.13 \\
\hline Adj. $\mathrm{R}^{2}$ & 0.27 & Adj. $\mathrm{R}^{2}$ & 0.13 \\
\hline DW Stat. & 1.95 & DW Stat. & 2.04 \\
\hline a - Uses cross-section weighting \\
\hline b - Uses cross-section SUR weighting
\end{tabular}

Table 7: Post-Crisis FGLS estimation

\begin{tabular}{l|l|l|l}
\hline Measurement $^{\mathrm{a}}$ & Value & Measurement $^{\mathrm{b}}$ & Value \\
\hline Coefficient & 0.19 & Coefficient & 0.1666 \\
\hline Std. Error & 0.0670 & Std. Error & 0.0672 \\
\hline t-Stat. & 2.83 & t-Stat. & 2.48 \\
\hline Prob. & $0.0051^{* * *}$ & Prob. & $0.0140^{* * *}$ \\
\hline $\mathrm{R}^{2}$ & 0.04 & $\mathrm{R}^{2}$ & 0.03 \\
\hline Adj. $\mathrm{R}^{2}$ & 0.03 & Adj. $\mathrm{R}^{2}$ & 0.02 \\
\hline DW Stat. & 1.99 & DW Stat. & 1.99 \\
\hline a - Uses cross-section weighting \\
\hline b - Uses cross-section SUR weighting
\end{tabular}


What is significant about these results is the dramatic loss of the market's impact on export pricing after the financial crisis of 2008. Using a FLGS regression with SUR weighting, the market coefficient value decreases by greater than $50 \%$ between the two periods, while both coefficients remain significant at the $99 \%$ confidence level.

The market's behavior is modeled in terms of a second order difference equation as shown in Equation (18) below:

$$
\epsilon_{t}=\Delta y_{t}-\alpha-\beta_{1} \Delta y_{t-1}
$$

Assuming that $\epsilon_{t}=0$ and solving for $y_{t}$ yields:

$$
\begin{gathered}
0=y_{t}-y_{t-1}-\alpha-\beta_{1}\left(y_{t-1}-y_{t-2}\right) \\
0=y_{t}-y_{t-1}-\alpha-\beta_{1} y_{t-1}+\beta y_{t-2} \\
0=y_{t}-y_{t-1}\left(\beta_{1}-1\right)-\alpha+\beta_{1} y_{t-2} \\
y_{t}=\alpha+y_{t-1}\left(\beta_{1}-1\right)-\beta_{1} y_{t-2}
\end{gathered}
$$

Using Equation (21) above and determining the characteristic roots provides insight as to how prices are behaving over time. Using the results for the full-period regression, $\beta_{1}=0.34$ and $\beta_{2}=-0.66$, leads to solving for the following characteristic roots:

$$
\begin{gathered}
r_{1}, r_{2}=\frac{-b_{1} \pm \sqrt{b_{1}^{2}-4 b_{2}}}{2} . \\
r_{1}, r_{2}=\frac{-0.34 \pm \sqrt{.34^{2}-4(-0.66)}}{2} \\
r_{1}, r_{2}=\frac{-0.34 \pm \sqrt{0.1156+2.64}}{2} \\
r_{1}, r_{2}=\frac{-0.34 \pm \sqrt{2.7556}}{2} \\
r_{1}, r_{2}=\frac{-0.34 \pm 1.66}{2} \\
r_{1}=-1 \text { and } r_{2}=0.66
\end{gathered}
$$

Given that the absolute value of the dominant root is equal to 1 , the system does not converge or diverge over time. The value of the second root does have economic significance. The system will, over time, tend toward its long-run equilibrium price.

For the purpose of this work, market structure is defined by the change in one exporter's price and the reaction of the market to this change. In a competitive market, if a single market agent changes its export price in a prior period, it should not impact the movement of the market price the following period. If the market participants change their export prices in a prior period, the effect of this change should be reflected in the next period.

The analysis begins with a panel regression using the differenced real export prices of the four exporters in this market. The model is constructed where the current real price of all participants is the dependent variable $\left(\Delta p_{t, i}\right)$. The variable $\Delta p_{t, i}$ is an $\mathrm{N}$ x 4 matrix of real export prices at time $t$ of the four market participants. The first independent variable $\left(\Delta x_{t-1, j}\right)$ is an $\mathrm{N} \times 3$ matrix consisting of oneperiod lag of real export prices of three Asian rice exporters. The second independent variable $\left(\Delta z_{t-1}\right)$ is the one-period lag of the fourth country's real export prices. There are actually four regressions which are run to determine how the market responds to price changes in the prior period.

A simple panel regression as shown in Equation 28 below models the impact of how the price changes at $t-1$ by three exporters acting as one entity along with the price change of the fourth exporter at $t$ - 1 influence the entire market's price changes at time $t$. The mod will help determine the pricing power of an individual exporter versus the influence on current prices of the other exporters in the market. If Thailand changes its export price at time $t$ - 1 , then in a competitive market it should have no influence 
on future market price movements vis-à-vis Vietnam, India and Pakistan and their pricing decisions at $t$-1. The price movements of all market participants should have adjusted in time $t$ and therefore Thailand's price change in $t$ - 1 has no impact on the response of the market in the period following its change. This process should hold for all exporters in the market. The independent variable $\Delta x_{t-1}$ is an $\mathrm{N}$ $\times 3$ matrix of export prices. This matrix represents three of the four exporting countries at time $t-1$. The constant $\alpha$ is the intercept term, and $\Delta z_{t-1}$ is a column vector of export prices for the fourth exporting country.

$$
\Delta p_{t}=\alpha+\beta_{2} \Delta x_{t-1}+\beta_{3} \Delta z_{t-1}+u_{t}
$$

The null hypothesis is $\beta_{2}>\beta_{3}$ for a competitive market and $\beta_{2}<\beta_{3}$ for a non-competitive market. If the market is a non-competitive market it means that one exporter influences the market price more than the other participants in the market. If all four cases show that $\beta_{2}=\beta_{3}=0$ then all exporters are acting independently. If the results show that the stand alone exporting country has more influence on current export prices, then that exporter is considered a price leader.

The next step in this analysis is to study the price impact of individual exporters, examined in relation to the rest of the market. If there is cointegration among the cross-section of variables, then those cointegrated variables share a long-term deterministic trend. The impact of cointegration is that it leads to spurious regression results with inflated $\mathrm{R}^{2}$ values and lower t-statistics. When cointegration exists, an error correction model must be employed to capture the true long-run relationships amongst the variables.

According to Engel and Granger (1987), two or more variables that are I(1) individually may be stationary, $\mathrm{I}(0)$ when formed in a linear combination. When this exists, the variables are cointegrated. When variables are cointegrated it means that one or more of the variables influence the long-run behavior of the system. The variables do not move back to their long-run equilibrium point, leading to spurious regression results.

Engel and Granger begin their work identifying the components of a cointegrated system ${ }^{10}$. For a stationary series, the variance of a vector of variables $x_{t}$ is finite and shocks have only temporary effects on the system which tends back to its natural equilibrium level. Given a vector of variables such as $x_{t}$, they are in equilibrium when a linear constant $\alpha^{\prime}$ is introduced to the systems such that

$$
\alpha^{\prime} x_{t}=0
$$

When the system is not in equilibrium then

$$
z_{t}=\alpha^{\prime} x_{t}
$$

In order to conform to the principles of economic theory, $z$ should take on small values. Engel and Granger then introduce models to allow for error-correcting cointegrated variables. The purpose of the error correction model is to allow variables to tend toward their natural long-run equilibrium state while allowing for dynamic short-run fluctuations.

When examining an $\mathrm{I}(1)$ and an $\mathrm{I}(0)$ series, the sum of these series will be $\mathrm{I}(1)$. If the parameters $a$ and $b$ are constants and $\mathrm{x}$ is a vector of variables that exhibit $\mathrm{I}(1)$ properties, then $a+b x_{t}$ also $\mathrm{I}(1)$. If $x_{t}$ and $y_{t}$ are both $\mathrm{I}(1)$ then their linear combination will also be $\mathrm{I}(1)$.

$$
\begin{gathered}
y_{t}=a+b x_{t} \\
z_{t}=\alpha^{\prime} x_{t} \\
z_{t}=x_{t}-a y_{t}
\end{gathered}
$$

The authors then examined the condition when $z_{t} \sim \mathcal{I}(d-b)$ and $b>0$. When both $y_{t}$ and $x_{t}$ are $\mathrm{I}(1)$, then $z_{t}$ is $\mathrm{I}(0)$. This is where the constant $\alpha^{\prime}$ neutralizes the long-run influence of $x_{t}$ on $y_{t}$ and $y_{t}$ on $x_{t}$ since $z_{t}=\left(\alpha ? x_{t} \sim I(d-b), b>0\right.$. In this work, since $x_{t}$ has N-components there may be more than one cointegrating vector. The possible number of cointegrating vectors, $r$, is $r_{\max }=N-1$. The

\footnotetext{
${ }^{10}$ Robert F. Engel and C.W.J. Granger, "Cointegration and Error Correction: Representation, Estimation and Testing", Econometrica, Vol. 55, No. 2, March 1987, pg. 253.
} 
cointegrating vectors exist in a matrix with a dimension of $\mathrm{N} \times \mathrm{r}$. The cointegrating rank of the matrix is $r$.

There are several issues with the Engel-Granger approach to correcting for cointegrating variables ${ }^{11}$. The first is its power to determine unit roots and cointegration. There could also be a simultaneous equation bias if causality runs in both directions between the dependent variable and the independent variable. A second issue of the Engel-Granger process is that it is a two-step process. Any error committed in the first step is then carried over into the second step. A final problem noted is that hypothesis testing about the cointegrating relationship estimated in the first step of the Engel-Granger process is not possible.

Johansen and Julius (1990) develop a test that incorporates a Vector Auto Regressive (VAR) process with $k$ lags of the dependent variable $y_{t}$. It relies on the analysis of the long-run coefficient matrix defined as:

$$
\Pi=\left(\sum_{i=1}^{k} \beta_{i}\right)-I_{N}
$$

where $\beta_{i}$ is a matrix of parameters and $I_{N}$ is the identity matrix. The rank of this matrix equals the number of cointegrating vectors.

Their work states that expecting the estimators to "behave better than the regression estimates"12 is because the estimator values take into consideration the error structure of the underlying process. In equilibrium, all of the $\Delta y_{t-i}=0$, with the expected value of the error-term equal to zero. The rank of this test is determined by its eigenvalues which are also the characteristic roots of the difference equation. The eigenvalues are noted as $\lambda_{i}$ with roots that are less than one when taking the absolute value. If there is cointegration then the rank of this matrix is not significantly different than zero.

The Johansen test provides two statistics, a trace value and a maximum eigenvalue. A trace test measures the number of cointegrating vectors. The null hypothesis is that the number of cointegrating vectors is less than or equal to a specific number of cointegrating vectors. The maximum number of cointegrating vectors is equal to $N-1$ where $N$ equals the number of parameters in the model. The maximum eigenvalue test examines each eigenvalue with a null that the number of cointegrating vectors is $N-1$. The alternative is that there are $k$ cointegrating vectors. These tests are specified as:

$$
\begin{gathered}
\lambda_{\text {trace }}(r)=-T \sum_{i=r+1}^{N} \ln \left(1-\hat{\lambda}_{i}\right) \\
\lambda_{\text {max }}(r, r+1)=-T\left[\ln \left(1-\hat{\lambda}_{r+1}\right]\right.
\end{gathered}
$$

where $T$ is the number of usable observations, trace. is the sum of eigenvalues of the long-run coefficient matrix, $r$ is the number of cointegrating vectors, $N$ is the number of variables in the model and $\lambda$ represents the value of each characteristic value.

The parameter matrices are square matrices $(N x N)$. Given that the $\Pi$ matrix is an $N x N$ matrix of vectors, the determinant of the matrix is $\Pi-\lambda I$. The characteristic equation of a square matrix is nth-degree polynomial equation defined as:

$$
\operatorname{det}(\Pi-\lambda I)=0
$$

Using the Johansen trace and eigenvalue test, each method confirms that the variables are not cointegrated. Appendix E below provides the results of these tests. The interpretation of these results indicates that there is no long-run trend between export prices. This does not preclude the possibility that there is a short-run relationship.

As stated earlier in this work, the Law of One Price holds when all four exporter prices are cointegrated. The results of the cointegration tests indicate that the market is segmented along product lines. Each exporter's commodity is viewed by consuming nations as being heterogeneous. Most likely each exporter's commodity is judged along qualitative differences. Whether or not this is the case, the

\footnotetext{
${ }^{11}$ Chris Brooks, "Introductory Econometrics for Finance", 2n edition, Cambridge University Press, 2008, Pg. 342.

${ }^{12}$ Soren Johansen, Statistical Analysis of Cointegration Vectors, Journal of Economic Dynamics and Control, Vol. 12, 1988, Pg. 231.
} 
issue is beyond the scope of this work. What can be inferred from these results is that the market is a non-competitive market whereby the market has leaders and followers.

Appendix D provides the details of the data used to examine stability conditions. For each regression, the residuals are examined to determine if a unit root exists. If unit roots do not exist, then the system is stable. The next step is to determine if the variables on the RHS of the equation are correlated with the residuals. If this condition exists then the estimator is inconsistent and biased, requiring modification of the model.

The unit root tests conducted include the Hadri, IPS, Phillips-Perron, and the Levin, Lui Chu t* tests. For all of the regressions used in this work the tests support rejecting the null of a common and individual unit root process in the residuals of the four regressions. Rejecting the null of a unit root process in the residuals, the system of equations is stable.

The variables on the RHS of the equation are then tested for correlation with the residuals of the regression. They are also tested for correlation with each other. If correlation exists then the standard errors of the coefficients are inflated and yield bias coefficient estimations. In Appendix D, the results show a minimum correlation coefficient of -0.004471 between variables on the RHS of the equation to a high of 0.006 . These results indicate that the variables on the RHS are i.i.d. as required for providing unbiased estimates.

The correlation between the variables on the RHS of the equation and the residuals also point to no significant correlation. The correlation coefficients range from a minimum of -0.097 to a maximum value of 0.138 . These results lead to the conclusion that there is no significant correlation between the variables on the RHS of the equation and the residuals of the regression.

Given the dominance of Thailand as a major exporter of rice it is expected that its changes in export price will have more of an influence in the market than the other three exporting countries. Given that Vietnam's rice exports are being perceived as less than optimal, with respect to India, Pakistan and Thailand, its price movements should have little impact on the market's response. The results are presented in Appendix A.

Examining the results for the pre-crisis and post-crisis periods shows a marked decline in the ability of exporters to exert its influence on export prices with one exception, Vietnam. Though it has lost some of its ability to influence prices given the estimated coefficient decreased from 0.45 (pre-crisis) to 0.24 (post-crisis), the decrease in the market's ability to influence price waned from 0.33 pre-crisis to 0.14 post-crisis. The results support that India and Vietnam were market leaders prior to the financial crisis. After the financial crisis, Thailand and Vietnam emerge as the leaders in this market. What is also important to note is that though Thailand and Vietnam emerge as price leaders, their ability to impact prices is not as great as India and Vietnam could during the pre-crisis period.

Comparing the Adjusted $\mathrm{R}^{2}$ for all of the regressions shows that the explanatory power of prior period prices has decreased in the post-crisis period compared to the pre-crisis. The $\mathrm{R}^{2}$ value decreased from 0.15 pre-crisis to 0.03 post-crisis. During the financial crisis, India imposed a ban on all non-basmati rice exports. The governments of Pakistan, Thailand and Vietnam all imposed trade restrictions to protect domestic rice prices from dramatic increases. Appendix B provides a timeline of specific government trade restrictions that contributed to increasing export prices.

\section{Conclusions and Suggestions for Further Research}

Before the financial crisis of 2008, India and Vietnam were price leaders in the Asian rice export market. During the crisis, the governments of these respective countries imposed trade restrictions while importers were bidding up prices through increased demand. As a result of this, the price mechanism was influenced by government policies in the post-crisis period. This is evident by the loss of the market's ability to influence prices.

It is important to note that the market did play an influential role in price determination pre-crisis. In all cases, the price coefficient is significant at the $99 \%$ confidence level for all estimates. Though the results show that the market was influential in determining prices, the country coefficients of India and Vietnam exceed the market coefficients. These two countries, before the financial crisis, were price leaders. In the post-crisis period Vietnam and Thailand are the market leaders. 
Based on these results, it is possible that government policies such as export bans, export quotas and export tariffs could be influential factors in governing rice export prices from this market. It is also possible that given the steep price increases during the crisis, importers found close substitutes for rice, and are still consuming these close substitutes. Finally, with India and Pakistan being the only two basmati rice exporters, these countries may have made a decision to focus on the export of basmati rice over $5 \%$ broken rice. This would support the rise of Thailand and Vietnam as leaders in the export of $5 \%$ broken rice.

A second factor that contributes to Thailand and Vietnam becoming price leaders for $5 \%$ broken rice is that India and Pakistan are leaders in the export of Basmati rice. Given their monopoly on the export of basmati rice and the demand for this commodity, it is natural for these exporters to specialize in the production and export of basmati rice.

\section{References}

1. Amarender A. Reddy. "Commodity Market Integration: Case of Asian Rice Markets." Centre for Studies in International Relations and Development (CSIRD), CSIRD Discussion Paper: 16/2006, April 2006: 1-19.

2. Baltagi, Badi and Qu Feng and Chihwa Kao. "A Lagrange Multiplier Test for Cross-Sectional Dependence in a Fixed Effects Panel Data Model." Center for Policy Research. Paper 193, 2012: 1-14.

3. Breusch, Trevor and Adrian Pagan. "A Simple Test for Heteroscedasticity and Random Coefficient Variation." Econometrica, Vol. 47, No. 5, September 1979: 1287-1294.

4. Calpe, Concepcion. "Rice International Commodity Profile." Food and Agricultural Organization of the United Nations, Market and Trades Division. December 2006: 2-20.

5. Chen, Chi-Chung and Bruce A. McCarl, and Ching-Cheng Chang, Spatial Equilibrium Modeling with Imperfectly Competitive Markets: An Application to Rice Trade, http://ageco.tamu.edu/faculty/mccarl/papers/736.pdf.

6. Chulaphan Wanvilai, Shwu-En Chen, Chalermpon Jatuporn and Wen-chi Huang, "Different Causal Relationships of Export Rice Prices in the International Rice Market." American-Eurasian Journal of Agricultural \& Environmental Science, No. 13 (2) 2013: 185 - 190.

7. Clarete, Ramon L. "Enhancing ASEAN's Resiliency to Extreme Rice Price Volatility." Asian Development Bank, No. 23, August 2012: 1-20.

8. Abbott, Philip C., Christopher Hurt, and Wallace E. Tyner. "What's Driving Food Prices in 2011." Farm Foundation, NFP, July 2011: 47.

9. Acharya, S.S., Ramesh Chand, P.S. Birthal, Shiv Kumar, and D.S. Negi. MARKET INTEGRATION AND PRICE TRANSMISSION IN INDIA: A CASE OF RICE AND WHEAT WITH SPECIAL REFERENCE TO THE WORLD FOOD CRISIS OF 2007/08. Article, Rome: FAO, 2012, 65.

10.Algieri, Bernardina. "Price Volatility, Speculation and Excessive Speculation in Commodity Markets sheep or shepherd behaviour." Zentrum für Entwicklungsforschung (ZEF) 166 (May 2012): 37.

11.Buyuksahin, Bahhatin, and H. Jeffrey Harris. "Do Speculators Drive Crude Oil Futures Prices?" The Energy Journal (IAEE) 32, no. 2 (2011): 167-202.

12.Heady, Derek, and Sheggan Fan. "Anatomy of a Crisis: The Causes and Consequences of Surging Food Prices." IFPRI Discussion Paper (International Food Policy Research Institute), 2008: 36.

13.Karp, Larry S., and Jeffrey M. Perloff. "Dynamic Oligopoly in the Rice Export Market." The Review of Economics and Statistics (MIT PRess) 71, no. 3 (August 1989): 462-470.

14.Lagi, Marco, Yavni Bar-Yam, Karla Z. Bertrand, and Yaneer Bar-Yam. "The Food Crises: A quantitative model of food prices including." September 21, 2011: 56.

15.Scott, H. Irwin, R. Sanders Dwight, and P. Merrin Robert. "Devil or Angel? The Role of Speculation in the Recent Commodity Price Boom (and Bust)." Journal of Agricultural and Applied Economics (Southern Agricultural Economics Association) 41, no. 2 (August 2009): 377-391.

16.Wailes, Eric J., and Eddie C. Chavez. "International Rice Baseline with Deterministic and Stochastic Projections, 2012-2021." World Rice Outlook, 2012: 81.

17.Working, Holbrook. "Futures Trading and Hedging." The American Economic Review (American Economic Association) 43, no. 3 (June 1953): 314-343. 
18.Working, Holbrook. "Hedging Reconsidered." Agricultural \& Applied Economics Association (Oxford University Press) 35, no. 4 (November 1953): 544-561.

19.Working, Holbrook. "New Concepts Concerning Futures Markets and Prices." American Economic Review (American Economic Association) 51, no. 2 (May 1961): 160-163.

20.Yumkella, Kandeh K., Laurian June Unnevehr, and Philip Garcia. "Noncompetitive Pricing And Exchange Rate Pass-Through In Selected U.S. And Thai Rice Markets." Journal of Agricultural and Applied Economics

(Southern Agricultural Economics Association) 26, no. 2 (December 1994): 406-417.

\section{Appendix A: Regression Results}

Table 8: Pre-Crisis country and market response to prior period price changes

\begin{tabular}{|c|c|c|c|c|c|c|c|c|}
\hline & India & Market & Pakistan & Market & Thailand & Market & Vietnam & Market \\
\hline Est. Coeff. & $\begin{array}{l}0.4730^{* *} \\
*\end{array}$ & $\begin{array}{l}0.3046^{* *} \\
*\end{array}$ & $\begin{array}{l}0.2344^{*} \\
*\end{array}$ & $\begin{array}{l}0.4120^{* *} \\
*\end{array}$ & $\begin{array}{l}0.2358^{* *} \\
*\end{array}$ & $\begin{array}{l}0.3930 * * \\
*\end{array}$ & $\begin{array}{l}0.4469^{* *} \\
*\end{array}$ & $\begin{array}{l}0.3318^{* *} \\
*\end{array}$ \\
\hline & $(0.0713)$ & $(0.0600)$ & $(0.1039)$ & $(0.0585)$ & $(0.0789)$ & $(0.0553)$ & $(0.0758)$ & $(0.0579)$ \\
\hline t-Stat. & 6.6336 & 5.0749 & 2.2567 & 7.0420 & 2.9886 & 7.0990 & 5.8994 & 5.7341 \\
\hline $\begin{array}{l}\text { Probabilit } \\
\mathrm{y}\end{array}$ & 0.0000 & 0.0000 & 0.0247 & 0.0000 & 0.0030 & 0.0000 & 0.0000 & 0.0000 \\
\hline $\mathrm{R}^{2}$ & 0.15 & & 0.15 & & 0.15 & & 0.14 & \\
\hline Adj. $\mathrm{R}^{2}$ & 0.14 & & 0.14 & & 0.14 & & 0.13 & \\
\hline DW Stat. & 1.99 & & 2.01 & & 2.02 & & 2.03 & \\
\hline
\end{tabular}

Table 9: Post-Crisis country and market response to prior period price changes

\begin{tabular}{|c|c|c|c|c|c|c|c|c|}
\hline & India & Market & Pakistan & Market & Thailand & Market & Vietnam & Market \\
\hline Est. Coeff. & 0.124469 & $0.1775^{* * *}$ & 0.00084 & $0.2111^{* * *}$ & $0.2614^{* *}$ & $0.1288^{*}$ & $0.2393 * *$ & $0.1350^{*}$ \\
\hline & $(0.1268)$ & $(0.0746)$ & $(0.1255)$ & $(0.0751)$ & $(0.1175)$ & $(0.0753)$ & $(0.1171)$ & $(0.0763)$ \\
\hline t-Stat. & 0.981642 & 2.378415 & 0.0067 & 2.811471 & 2.22565 & 1.711553 & 2.044371 & 1.769152 \\
\hline Probability & 0.3274 & 0.0183 & 0.9947 & 0.0054 & 0.0271 & 0.0884 & 0.0421 & 0.0783 \\
\hline $\mathrm{R}^{2}$ & 0.03 & & 0.04 & & 0.03 & & 0.03 & \\
\hline Adj. $R^{2}$ & 0.02 & & 0.03 & & 0.02 & & 0.02 & \\
\hline DW Stat. & 1.99 & & 1.98 & & 1.99 & & 1.98 & \\
\hline
\end{tabular}

Standard errors are in parentheses.

$* * *, * *, *$ indicates significance at the 1,5 , and 10 percent levels, respectively 


\section{Appendix B: Government Export and Import Policies}

\begin{tabular}{|c|c|c|c|c|}
\hline \multirow{2}{*}{ Month/Year } & \multicolumn{4}{|c|}{ Major Incidents } \\
\hline & India & Vietnam & Thailand & Others \\
\hline Jun. 2006 & Export of pulses banned. & & & \\
\hline Feb. 2007 & Export of wheat banned. & & & \\
\hline May 2007 & $\begin{array}{l}\text { Minimum support price (MSP) of rice for 2007-08 } \\
\text { announced at 6,450 rupees per ton for common } \\
\text { varieties } \\
\text { varieties }{ }^{(1)} \text { (Mnd } 6,750 \text { rupees per ton for Grade A }\end{array}$ & & & \\
\hline Jul. 2007 & & $\begin{array}{l}\text { The Vietnam Food Association (VFA) announced } \\
\text { a ban on the signing of new rice-export contracts. } \\
\text { The announcement was based on the achievement } \\
\text { of annual target exports. }\end{array}$ & & \\
\hline Sep. 2007 & & $\begin{array}{l}\text { The government formally approved the } \\
\text { announcement by the VFA. }\end{array}$ & & \\
\hline Oct. 2007 & $\begin{array}{l}\text { MSP of rice raised by } 500 \text { rupees per ton and } \\
\text { export of non-basmati rice banned ( }(0 \mathrm{ct} 9) \text {. The } \\
\text { ban was lifted on Oct } 31 \text { and a minimum export } \\
\text { price (MEP) for non-basmati rice was set at } \$ 425 \\
\text { per ton. }\end{array}$ & & & \\
\hline Nov. 2007 & $\begin{array}{l}\text { MSP of rice raised by a further } 500 \text { rupees per ton } \\
\text { (Nov 15). }\end{array}$ & & & \\
\hline Dec. 2007 & $\begin{array}{l}\text { MEP for non-basmati rice raised to } 500 \text { dollars per } \\
\text { ton (Dec 27). }\end{array}$ & & & China imposed export tax on rice. \\
\hline Jan. 2008 & & $\begin{array}{l}\text { The government lifted the ban on the signing of } \\
\text { new rice-export contracts. }\end{array}$ & & $\begin{array}{l}\text { Egypt announced a voluntary export control of rice by } \\
\text { private exporters. }\end{array}$ \\
\hline Mar. 2008 & $\begin{array}{l}\text { MEP for non-basmati rice raised to } \$ 650 \text { per ton; } \\
\text { that for basmati rice set at } \$ 900 \text { per ton (March 5). } \\
\text { Export of edible oils banned (March 17). MEP } \\
\text { for non-basmati and basmati rice raised to } \$ 1,000 \\
\text { and \$1,100 per ton, respectively (March 27). }\end{array}$ & $\begin{array}{l}\text { Due to the global price hikes, the govermment } \\
\text { again placed the ban on the signing of new } \\
\text { rice-export contracts. }\end{array}$ & & $\begin{array}{l}\text { Egypt banned rice export until October } 2008 . \\
\text { Cambodia banned rice export. }\end{array}$ \\
\hline Apr. 2008 & $\begin{array}{l}\text { Export of non-basmati rice banned and MEP for } \\
\text { basmati rice raised to } \$ 1,200 \text { per ton (April 1). }\end{array}$ & & $\begin{array}{l}\text { The government decided to release } 2.1 \\
\text { million tons of stock to the domestic } \\
\text { market. } \\
\text { FOB of } 100 \% \text { Thai white rice rose to } \\
\text { over } \$ 1,000 \text { per ton. }\end{array}$ & $\begin{array}{l}\text { Pakistan announced a minimum export price. The } \\
\text { government of the Philippines announced it would } \\
\text { invite tenders of } 500 \text { thousand tons of rice for import, } \\
\text { but there was no tender. Brazil temporally banned rice } \\
\text { export. In Haiti, the rice price hike caused a riot. }\end{array}$ \\
\hline
\end{tabular}

\section{Appendix B: Government Export and Import Policies (cont.)}



Source: Nikkei Telecom21, Reuters, Bangkok Post, The Hindu Business Line, and Vietnam Agricultural News.

Notes: (1) Varieties for which grain length is less than 2.5 times grain width. (2) Varieties for which grain length is 2.5 times grain width or greater. 


\section{Appendix C: AIC \& SBIC Test Results}

Model: $\Delta y_{i, t}=\alpha+\Delta y_{i, t-k}+e_{i, t}$.

\begin{tabular}{c|c|c}
\hline Lag & AIC & SBIC \\
\hline 1 & -2.749736 & -2.735339 \\
\hline 2 & -1.697317 & -1.682828 \\
\hline 3 & -1.131058 & -1.116476 \\
\hline 4 & -0.785473 & -0.770798 \\
\hline 5 & -0.55659 & -0.541818 \\
\hline 6 & -0.401522 & -0.386654 \\
\hline 7 & -0.289243 & -0.274278 \\
\hline 8 & -0.214474 & -0.199409 \\
\hline 9 & -0.148854 & -0.133688 \\
\hline 10 & -0.082241 & -0.066973 \\
\hline 11 & -0.00883 & 0.006547 \\
\hline 12 & 0.062825 & 0.078303 \\
\hline
\end{tabular}




\section{Appendix D: Correlation Coefficient and Unit Root Tests}

\begin{tabular}{r|r|r|l}
\hline & \multicolumn{4}{c}{ Pre-Crisis Analysis } \\
\hline Country & Rest of Mkt & Residuals & Conclusion \\
\hline India & -0.004471 & -0.000474 & No Correlation with market variable or with residuals \\
\hline Pakistan & 0.000834 & 0.020723 & No Correlation with market variable or with residuals \\
\hline Thailand & -0.003218 & 0.074136 & No Correlation with market variable or with residuals \\
\hline Vietnam & 0.000607 & -0.097388 & No Correlation with market variable or with residuals \\
\hline \multicolumn{4}{|c}{ Post-Crisis Analysis } \\
\hline Country & Rest of Mkt & Residuals & \\
\hline India & 0.006260 & -0.021196 & No Correlation with market variable or with residuals \\
\hline Pakistan & 0.000225 & -0.001853 & No Correlation with market variable or with residuals \\
\hline Thailand & -0.001042 & -0.072058 & No Correlation with market variable or with residuals \\
\hline Vietnam & -0.002212 & 0.138364 & No Correlation with market variable or with residuals \\
\hline
\end{tabular}

\begin{tabular}{lllll}
\hline \multicolumn{5}{c}{ India Residual Unit Root Test: Pre-Crisis } \\
\hline Test & Null Hypothesis & Statistic & t-Stat & H0: Conclusion \\
\hline Levin, Lui \& Chu t* & Common unit root process & -1.3306 & 0.0916 & Reject \\
\hline Im, Pesaran and Shin W-stat & Individual Unit Root Process & -6.5316 & 0.0000 & Reject \\
\hline Hadri & Stationarity & -1.0752 & 0.8589 & Do Not Reject \\
\hline Phillips-Perron & Panel has a unit root process & 131.776 & 0.0000 & Reject \\
\hline
\end{tabular}

\begin{tabular}{|c|c|c|c|c|}
\hline \multicolumn{5}{|c|}{ India Residual Unit Root Test: Post-Crisis } \\
\hline Test & Null Hypothesis & Statistic & t-Stat & H0: Conclusion \\
\hline Levin, Lui \& Chu t* & Common unit root process & -1.3306 & 0.0916 & Reject \\
\hline Im, Pesaran and Shin W-stat & Individual Unit Root Process & -6.5316 & 0.0000 & Reject \\
\hline Hadri & Stationarity & -1.0752 & 0.8589 & Do Not Reject \\
\hline Phillips-Perron & Panel has a unit root process & 131.776 & 0.0000 & Reject \\
\hline \multicolumn{5}{|c|}{ Pakistan Residual Unit Root Test: Pre-Crisis } \\
\hline Test & Null Hypothesis & Statistic & t-Stat & H0: Conclusion \\
\hline Levin, Lui \& Chu t* & Common unit root process & -7.5679 & 0.0000 & Reject \\
\hline Im, Pesaran and Shin W-stat & Individual Unit Root Process & -7.4897 & 0.0000 & Reject \\
\hline Hadri & Stationarity & -1.3083 & 0.9046 & Do Not Reject \\
\hline Phillips-Perron & Panel has a unit root process & 109.451 & 0.0000 & Reject \\
\hline \multicolumn{5}{|c|}{ Pakistan Residual Unit Root Test: Post-Crisis } \\
\hline Test & Null Hypothesis & Statistic & t-Stat & H0: Conclusion \\
\hline Levin, Lui \& Chu t* & Common unit root process & -1.2435 & 0.1068 & Do Not Reject \\
\hline Im, Pesaran and Shin W-stat & Individual Unit Root Process & -6.5325 & 0.0000 & Reject \\
\hline Hadri & Stationarity & -1.1437 & 0.8736 & Do Not Reject \\
\hline Phillips-Perron & Panel has a unit root process & 131.943 & 0.0000 & Reject \\
\hline
\end{tabular}




\begin{tabular}{|c|c|c|c|c|}
\hline \multicolumn{5}{|c|}{ Thailand Residual Unit Root Test: Pre-Crisis } \\
\hline Test & Null Hypothesis & Statistic & t-Stat & H0: Conclusion \\
\hline Levin, Lui \& Chu t* & Common unit root process & -7.3012 & 0.0000 & Reject \\
\hline Im, Pesaran and Shin W-stat & Individual Unit Root Process & -7.3552 & 0.0000 & Reject \\
\hline Hadri & Stationarity & -1.3774 & 0.9158 & Do Not Reject \\
\hline Phillips-Perron & Panel has a unit root process & 94.0166 & 0.0000 & Reject \\
\hline \multicolumn{5}{|c|}{ Thailand Residual Unit Root Test: Post-Crisis } \\
\hline Test & Null Hypothesis & Statistic & t-Stat & H0: Conclusion \\
\hline Levin, Lui \& Chu t* & Common unit root process & -0.1223 & 0.4513 & Do Not Reject \\
\hline Im, Pesaran and Shin W-stat & Individual Unit Root Process & -6.5238 & 0.0000 & Reject \\
\hline Hadri & Stationarity & -1.1729 & 0.8796 & Do Not Reject \\
\hline Phillips-Perron & Panel has a unit root process & 131.839 & 0.0000 & Reject \\
\hline \multicolumn{5}{|c|}{ Vietnam Residual Unit Root Test: Pre-Crisis } \\
\hline Test & Null Hypothesis & Statistic & t-Stat & H0: Conclusion \\
\hline Levin, Lui \& Chu t* & Common unit root process & -7.1178 & 0.0000 & Reject \\
\hline Im, Pesaran and Shin W-stat & Individual Unit Root Process & -7.3800 & 0.0000 & Reject \\
\hline Hadri & Stationarity & -1.3156 & 0.9059 & Do Not Reject \\
\hline Phillips-Perron & Panel has a unit root process & 98.1843 & 0.0000 & Reject \\
\hline \multicolumn{5}{|c|}{ Vietnam Residual Unit Root Test: Post-Crisis } \\
\hline Test & Null Hypothesis & Statistic & t-Stat & H0: Conclusion \\
\hline Levin, Lui \& Chu t* & Common unit root process & -3.4493 & 0.0003 & Reject \\
\hline Im, Pesaran and Shin W-stat & Individual Unit Root Process & -6.7632 & 0.0000 & Reject \\
\hline Hadri & Stationarity & -0.7597 & 0.7763 & Do Not Reject \\
\hline Phillips-Perron & Panel has a unit root process & 125.738 & 0.0000 & Reject \\
\hline
\end{tabular}

\section{Appendix E: Johansen Cointegration Test Results}

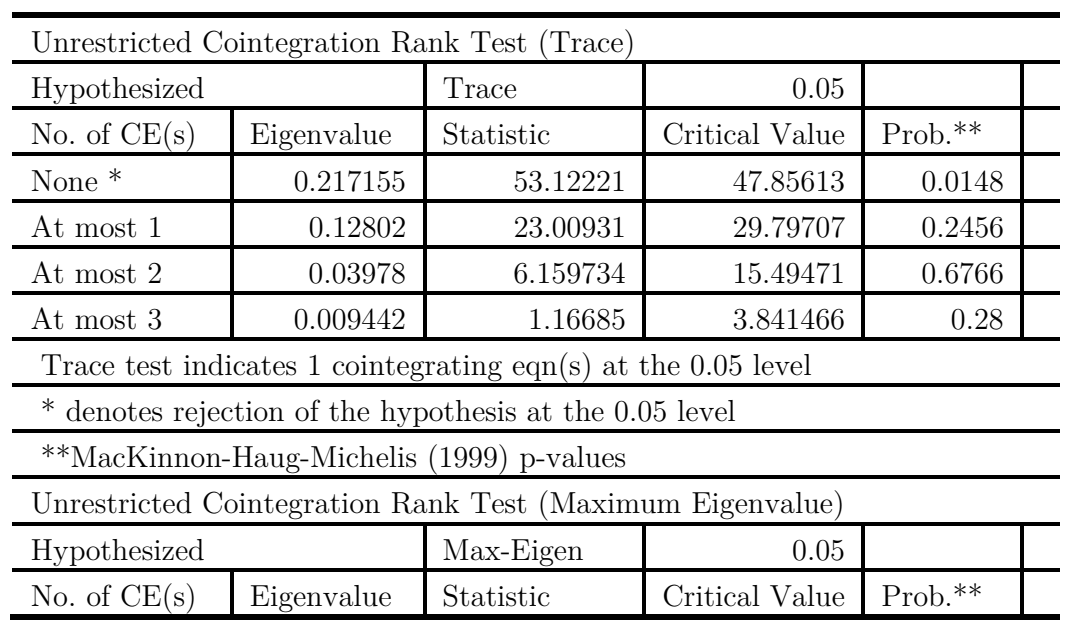




\begin{tabular}{|c|c|c|c|c|}
\hline None * & 0.217155 & 30.1129 & 27.58434 & 0.0232 \\
\hline At most 1 & 0.12802 & 16.84957 & 21.13162 & 0.1792 \\
\hline At most 2 & 0.03978 & 4.992884 & 14.2646 & 0.7427 \\
\hline At most 3 & 0.009442 & 1.16685 & 3.841466 & 0.28 \\
\hline \multicolumn{5}{|c|}{ Max-eigenvalue test indicates 1 cointegrating eqn(s) at the 0.05 level } \\
\hline \multicolumn{5}{|c|}{$*$ denotes rejection of the hypothesis at the 0.05 level } \\
\hline \multicolumn{5}{|c|}{ **MacKinnon-Haug-Michelis (1999) p-values } \\
\hline \multicolumn{5}{|c|}{ Unrestricted Cointegrating Coefficients (normalized by $b^{\prime *} \mathrm{~S} 11^{*} \mathrm{~b}=\mathrm{I}$ ): } \\
\hline F_IND & F_PAK & F_THA & F_VNM & \\
\hline-0.02844 & -0.044471 & 0.004764 & 0.077975 & \\
\hline 0.040891 & -0.007833 & -0.012556 & -0.046894 & \\
\hline 0.003474 & -0.007173 & -0.011909 & 0.014735 & \\
\hline-0.028824 & 0.007842 & 0.003432 & 0.004222 & \\
\hline
\end{tabular}

Unrestricted Adjustment Coefficients (alpha):

\begin{tabular}{l|r|r|r|r|l}
\hline D(F_IND) & -4.012386 & -2.168769 & 0.97166 & 0.630402 & \\
\hline D(F_PAK) & 2.020228 & -0.055054 & 1.795845 & 0.917267 & \\
\hline D(F_THA) & -4.892219 & -2.713394 & 3.236506 & -0.175835 & \\
\hline D(F_VNM) & -5.871788 & 0.703437 & 1.590588 & 0.192969 & \\
\hline 1 Cointegrating Equation(s): & Log likelihood & -1906.265 & & \\
\hline Normalized cointegrating coefficients (standard error in parentheses) & \\
\hline F_IND & F_PAK & F_THA & F_VNM & & \\
\hline & 1.563676 & -0.167514 & -2.741749 & & \\
\hline & -0.2919 & -0.07887 & -0.36813 & & \\
\hline
\end{tabular}

\begin{tabular}{l|r|l|l|l|l}
\hline Adjustment coefficients (standard error in parentheses) & & \\
\hline $\mathrm{D}\left(\mathrm{F} \_\right.$IND $)$ & 0.114112 & & & & \\
\hline & -0.03517 & & & & \\
\hline $\mathrm{D}\left(\mathrm{F} \_\right.$PAK $)$ & -0.057455 & & & & \\
\hline & -0.03774 & & & & \\
\hline $\mathrm{D}\left(\mathrm{F} \_\mathrm{THA}\right)$ & 0.139135 & & & & \\
\hline & -0.05623 & & & & \\
\hline $\mathrm{D}\left(\mathrm{F} \_\right.$VNM $)$ & 0.166994 & & & & \\
\hline & -0.03883 & & & & \\
\hline 2 Cointegrating Equation(s): & Log likelihood & -1897.84 & & \\
\hline
\end{tabular}

Normalized cointegrating coefficients (standard error in parentheses)

\begin{tabular}{r|r|r|r|r|l}
\hline F_IND & F_PAK & F_THA & F_VNM & & \\
\hline 1 & 0 & -0.291827 & -1.32088 & & \\
\hline & & -0.06457 & -0.1333 & & \\
\hline 0 & 1 & 0.0795 & -0.908673 & & \\
\hline & & -0.05927 & -0.12236 & & \\
\hline
\end{tabular}

\begin{tabular}{l|r|r|l|l|l}
\hline Adjustment coefficients (standard error in parentheses) & \multicolumn{2}{l}{} \\
\hline $\mathrm{D}(\mathrm{F}$ _IND) & 0.025429 & 0.195423 & & & \\
\hline & -0.06069 & -0.05502 & & & \\
\hline $\mathrm{D}\left(\mathrm{F} \_\mathrm{PAK}\right)$ & -0.059706 & -0.08941 & & & \\
\hline & -0.0661 & -0.05992 & & & \\
\hline
\end{tabular}




\begin{tabular}{l|r|r|r|r|l}
\hline $\mathrm{D}\left(\mathrm{F} \_\right.$THA $)$ & 0.028181 & 0.238816 & & & \\
\hline & -0.09758 & -0.08847 & & & \\
\hline $\mathrm{D}\left(\mathrm{F} \_\right.$_VNM $)$ & 0.195758 & 0.255614 & & & \\
\hline & -0.06791 & -0.06157 & & & \\
\hline
\end{tabular}

Normalized cointegrating coefficients (standard error in parentheses)

\begin{tabular}{|c|c|c|c|c|}
\hline F_IND & F_PAK & F_THA & F_VNM & \\
\hline \multirow[t]{2}{*}{1} & 0 & 0 & -1.682865 & \\
\hline & & & -0.36107 & \\
\hline \multirow[t]{2}{*}{0} & 1 & 0 & -0.81006 & \\
\hline & & & -0.15786 & \\
\hline \multirow[t]{2}{*}{0} & 0 & 1 & -1.24041 & \\
\hline & & & -1.11163 & \\
\hline
\end{tabular}

Adjustment coefficients (standard error in parentheses)

\begin{tabular}{l|r|r|r|r|l}
\hline $\mathrm{D}\left(\mathrm{F} \_\right.$IND $)$ & 0.028805 & 0.188454 & -0.003456 & & \\
\hline & -0.06066 & -0.05554 & -0.0218 & & \\
\hline $\mathrm{D}\left(\mathrm{F} \_\mathrm{PAK}\right)$ & -0.053467 & -0.102291 & -0.01107 & & \\
\hline & -0.06568 & -0.06014 & -0.02361 & & \\
\hline $\mathrm{D}\left(\mathrm{F} \_\mathrm{THA}\right)$ & 0.039426 & 0.215602 & -0.027781 & & \\
\hline & -0.09654 & -0.08841 & -0.03471 & & \\
\hline $\mathrm{D}\left(\mathrm{F} \_\mathrm{VNM}\right)$ & 0.201284 & 0.244205 & -0.055748 & & \\
\hline & -0.06764 & -0.06194 & -0.02431 & & \\
\hline
\end{tabular}

